\title{
Neovascularisation and the induction of cell adhesion molecules in response to degradation products from orthopaedic implants
}

\author{
Najat Al-Saffar, James T L Mah, Yoshinori Kadoya, Peter A Revell
}

\begin{abstract}
Objectives-To characterise the cellular interactions and the mechanisms involved in the recruitment of inflammatory macrophages and $T$ cells to the bone implant interface in 30 patients with aseptically loosened orthopaedic prostheses.

Methods-Cell adhesion molecules E-selectin, VCAM-1, ICAM-1 and the receptors LFA-1 and CR3 were immunolocalised on cryostat sections of the bone-implant interface obtained during revision arthroplasty. The percentage of expression on vascular endothelium was determined on serial sections.

Results-E-selectin was upregulated on different vessels in 21 patients. Its expression correlated strongly with the presence of metal wear debris. VCAM-1 was detected on vessels in six patients only, and was coexpressed with E-selectin in three patients with metal debris. VCAM-1 was more frequently observed in the lining cells on the implant side. ICAM-1 was upregulated on vessels on the bone side only in 13 patients, and was more strongly expressed on aggregates of macrophages and multinucleated giant cells on the implant side. These macrophage aggregates coexpressed both ICAM-1 and CR3.
\end{abstract}

Conclusion-Our findings implicate the contribution of three different pathways in the recruitment of inflammatory cells to the joint in response to orthopaedic implant wear particles. The association of E-selectin expression and metal debris may suggest hypersensitivity reactions. Finally, the simultaneous expression of ICAM-1 and CR3 on the same macrophages on the implant side may predict an additional function of these molecules in homotypic adhesion/cell aggregation that precede differentiation of phagocytes to multinucleated giant cells.

Department of Histopathology, The Royal Free Hospital School of Medicine, London NW3 2PF, United Kingdom N Al-Saffar J T L Mah Y Kadoya P A Revel Correspondence to: Dr N Al-Saffar. and bone necrosis around stable and well fixed implants that show no sign of loosening. ${ }^{12}$ Various studies demonstrated that bone loss

Osteoclastic bone resorption is a well documented phenomenon in association with Considerable attention has focused on this aseptic loosening of total joint replacements. adjacent to orthopaedic implants is linked to a local inflammatory cellular response at the bone-implant interface. ${ }^{3}$

Histological assessment of the interface membranes by our group and others indicates that these tissues develop initially in a form of fibrous stroma with a small number of macrophages and few or no vessels present. ${ }^{4}$ In comparison, membranes retrieved during revision of loosened or well fixed implants in patients with radiographic evidence of focal or progressive osteolysis show a high degree of vascularisation and cellular infiltrate predominated by two potential immune cells, macrophages and $\mathrm{T}$ lymphocytes. It is widely accepted that these cells accumulate in response to the local release of particulate wear debris generated from various types of implant material..$^{5-7}$ Corrosion of metal and wear of polyethylene components or fragmentation of polymethylmethacrylate bone cement have been found to be the major cause. The mechanism responsible for the entry and accumulation of immune competent cells in the bone-implant interface is not yet clearly defined. However, the process of neovascularisation and the activation of vascular endothelium may have a major role.

Neovascularisation is essential in wound healing and tissue repair, and plays an important role in acute and chronic inflammatory conditions. ${ }^{8}$ At sites of inflammation or antigenic stimuli, vascular endothelial cells have been shown to exhibit phenotypic and morphological similarity to those of high endothelial venules in lymphoid tissues. ${ }^{9}$ Furthermore, the earlier observations of the induction of HLA-DR expression on endothelial cells, ${ }^{10}$ production of interleukin (IL)-1, IL-6, tumour necrosis factor (TNF) $\alpha$ and other cytokines, and the capacity to act as antigen-presenting cells ${ }^{11}{ }^{12}$ suggest the participation of these cells in immune function. Endothelial cells are now known to play a key role in the chemotaxis, adhesion and transvascular migration of leucocytes during inflammatory reactions. ${ }^{13}{ }^{14}$ Vascular endothelial cells have been found to express at least three types of cytokine inducible adhesion molecules during activation. ${ }^{15-17}$ Endothelial leucocyte adhesion molecule-1 (ELAM-1) is now termed E-selectin; this glycoprotein belongs to the LEC-CAM (lectin, epidermal growth factor (EGF) and complement related) family of adhesion molecules. ${ }^{18}{ }^{19}$ E-selectin is important for neutrophil recruitment and may also participate in adhesion of $\mathrm{T}$ lymphocytes and 
Table 1 Clinical data of the patients

\begin{tabular}{|c|c|c|c|c|}
\hline $\begin{array}{l}\text { Patient } \\
\text { No }\end{array}$ & Sex/Age & $\begin{array}{l}\text { foint involved/ } \\
\text { Rev. No }\end{array}$ & $\begin{array}{l}\text { Duration } \\
\text { of implant }\end{array}$ & $\begin{array}{l}\text { Original joint } \\
\text { disease }\end{array}$ \\
\hline 1 & $F / 46$ & Hip/1 & $11 \mathrm{yr}$ & Sec.OA/CDH \\
\hline 2 & $\mathrm{M} / 62$ & Knee/1 & 18 months & OA \\
\hline 3 & $\mathrm{M} / 46$ & Knee/1 & $3 \mathrm{yr}$ & Sec.OA/PT \\
\hline 4 & $\mathrm{~F} / 82$ & Knee/1 & $15 \mathrm{yr}$ & $\mathrm{OA}$ \\
\hline 5 & $\mathrm{~F} / 61$ & $\mathrm{Hip} / 2$ & $4.5 \mathrm{yr}$ & $\mathrm{OA}$ \\
\hline 6 & $\mathrm{~F} / 79$ & $\mathrm{Hip} / 1$ & $4 \mathrm{yr}$ & $\mathrm{RA}$ \\
\hline 7 & M/57 & $\mathrm{Hip} / 1$ & $6 \mathrm{yr}$ & $\mathrm{RA}$ \\
\hline 8 & $\mathrm{M} / 58$ & Knee/1 & 16 months & $\mathrm{OA}$ \\
\hline 9 & $\mathrm{~F} / 48$ & $\mathrm{Hip} / 2$ & $2 \mathrm{yr}$ & $\mathrm{RA}$ \\
\hline 10 & M/56 & Hip/1 & $4 \mathrm{yr}$ & $\mathrm{OA}$ \\
\hline 11 & M/76 & Knee/1 & $2 \cdot 5 \mathrm{yr}$ & OA \\
\hline 12 & $\mathrm{M} / 78$ & $\mathrm{Hip} / 1$ & $22 \mathrm{yr}$ & $\mathrm{RA}$ \\
\hline 13 & $M$ & Knee & N/A & N/A \\
\hline 14 & $\mathrm{M} / 38$ & $\mathrm{Hip} / 1$ & $13 \mathrm{yr}$ & Sec.OA/ON \\
\hline 15 & $F / 57$ & $\mathrm{Hip} / 2$ & $3 \mathrm{yr}$ & OA \\
\hline 16 & $\mathrm{M} / 50$ & Hip/2 & $7 \mathrm{yr}$ & $\mathrm{OA}$ \\
\hline 17 & M/53 & Hip & $5 \mathrm{yr}$ & $\mathrm{OA}$ \\
\hline 18 & $\mathrm{~F} / 63$ & Knee/1 & $10 \mathrm{yr}$ & $\mathrm{RA}$ \\
\hline 19 & $\mathrm{~F} / 54$ & Hip/1 & $10 \mathrm{yr}$ & Sec.OA/CDH \\
\hline 20 & $\mathrm{~F} / 60$ & Hip/1 & $10 \mathrm{yr}$ & $\mathrm{OA}$ \\
\hline 21 & $\mathrm{~F} / 34$ & $\mathrm{Hip} / 2$ & $7 \mathrm{yr}$ & RA \\
\hline 22 & $\mathrm{~F} / 85$ & $\mathrm{Hip} / 1$ & $11 \mathrm{yr}$ & $\mathrm{OA}$ \\
\hline 23 & $\mathrm{~F} / 78$ & Knee/1 & $5.5 \mathrm{yr}$ & $\mathrm{OA}$ \\
\hline 24 & $F / 42$ & $\mathrm{Hip} / 1$ & $3 \mathrm{yr}$ & OA \\
\hline 25 & M/66 & Knee/1 & $9 \mathrm{yr}$ & $\mathrm{RA}$ \\
\hline 26 & $\mathrm{M} / 80$ & Knee/1 & $2 \mathrm{yr}$ & $\mathrm{OA}$ \\
\hline 27 & $\mathrm{~F} / 77$ & Knee/2 & $4 \mathrm{yr}$ & $\mathrm{OA}$ \\
\hline 28 & $\mathrm{~F} / 70$ & $\mathrm{Hip} / 1$ & $5 \mathrm{yr}$ & $\mathrm{OA}$ \\
\hline 29 & $\mathrm{~F} / 76$ & $\mathrm{Hip} / 1$ & 8 months & $\mathrm{RA}$ \\
\hline 30 & $\mathrm{~F} / 72$ & $\mathrm{Hip} / 1$ & $16 \mathrm{yr}$ & Sec.OA/PT \\
\hline
\end{tabular}

$\mathrm{OA}=$ Osteoarthritis; $\mathrm{RA}=$ rheumatoid arthritis; Sec. = secondary; $\mathrm{CDH}=$ congenital dysplasia dislocation of the hip; PT = post-traumatic; ON = osteonecrosis; Rev. = revision; N/A = data no available.

cells of the monocytic lineages. ${ }^{20-22}$ Vascular cell adhesion molecule-1 (VCAM-1) and intercellular adhesion molecule-1 (ICAM-1) are members of the immunoglobulin gene superfamily. ${ }^{23}$ Upregulation of these two adhesion molecules on activated endothelium mediates the binding of different leucocyte subsets through their counter receptors which include the $T$ cells ligand VLA-4 ( $\alpha 4 \mathrm{~B} 1, \mathrm{CD} 49 \mathrm{~d} /$ CD29) which is recognised by VCAM- $1{ }^{24}$ LFA-1 (CD11a/CD18) which is expressed by all leucocytes, ${ }^{25}$ and Mac-1 (CR3, CD11b/ CD18) which is expressed on myeloid cells, are both recognised by ICAM- $1 .^{26}$

Previous work showed that the development of inflammatory reactions in inflamed synovium is associated with vascular growth and upregulated expression of the three adhesion molecules, which is accompanied by increased mononuclear cell infiltrate. ${ }^{27}$ The bone-implant interface exhibits a number of

Table 2 Antibodies used in the study

\begin{tabular}{|c|c|c|c|c|}
\hline Antibody & Dilution & Specificity & Type/Class & Source \\
\hline $1 \cdot 2 \mathrm{~B} 6$ & $1 / 10$ & E-Selectin & $\begin{array}{l}\text { Culture supernatant/ } \\
\text { Mouse IgG1 }\end{array}$ & Dr Haskard \\
\hline $1.4 \mathrm{C} 3$ & $1 / 10$ & VCAM-1 & $\begin{array}{l}\text { Culture supernatant/ } \\
\text { Mouse IgG1 }\end{array}$ & Dr Haskard \\
\hline TS1/22 (CD11a) & $1 / 10$ & LFA-1 & $\begin{array}{l}\text { Culture supernatant/ } \\
\text { Mouse IgG1 }\end{array}$ & Dr Haskard \\
\hline ICAM-1 & $1 / 50$ & $\begin{array}{l}\text { ICAM-1, } 90 \mathrm{kDa} \\
\text { membrane } \\
\text { glycoprotein }\end{array}$ & Purified mouse IgG1 & Genzyme UK \\
\hline CD11b & $1 / 50$ & C3bi receptor & $\begin{array}{l}\text { Culture supernatant/ } \\
\text { Mouse IgG1 }\end{array}$ & Dako \\
\hline EBM11 & $1 / 50$ & CD68/macrophages & $\begin{array}{l}\text { Culture supernatant/ } \\
\text { Mouse IgG1 }\end{array}$ & Dako \\
\hline CD4 & $1 / 20$ & Helper T cells & $\begin{array}{l}\text { Culture supernatant/ } \\
\text { Mouse IgG1 }\end{array}$ & Dako \\
\hline $\mathrm{CD} 8$ & $1 / 20$ & Suppressor T cells & $\begin{array}{l}\text { Culture supernatant/ } \\
\text { Mouse IgG1 }\end{array}$ & Dako \\
\hline CD45RA & $1 / 20$ & Naïve $T$ cells & $\begin{array}{l}\text { Purified ascites/ } \\
\text { Mouse IgG1 }\end{array}$ & Serotec \\
\hline CD45RO & $1 / 50$ & $\begin{array}{l}\text { UCHL-1/memory } \\
\text { T cells }\end{array}$ & $\begin{array}{l}\text { Culture supernatant/ } \\
\text { Mouse IgG1 }\end{array}$ & Dako \\
\hline $5 \mathrm{~B} 5$ & $1 / 50$ & Prolyl 4-hydroxylase & $\begin{array}{l}\text { Culture supernatant/ } \\
\text { Mouse IgG1 }\end{array}$ & Dako \\
\hline $\begin{array}{l}\text { Von Willebrand } \\
\text { factor }\end{array}$ & $1 / 200$ & $\begin{array}{l}\text { Factor VIII related } \\
\text { antigen }\end{array}$ & $\begin{array}{l}\text { Purified rabbit } \\
\text { antiserum }\end{array}$ & Dako \\
\hline
\end{tabular}

structural features and cellular immune reactions often seen in rheumatoid synovium. These include synovial lining hyperplasia, neovascularisation, the presence of perivascular aggregates of functionally distinct subsets of $T$ lymphocytes and macrophages, and the development of foreign body multinucleated giant cells (FBGCs). This study aimed to investigate the possible role of different types of orthopaedic implant particulate debris in the induction of vascular endothelial adhesion molecules and their ligands on different cells in the bone-implant interface, and to assess their role in the initiation of the cellular inflammatory response in these membranes.

\section{Patients and methods}

Thirty patients who had osteolysis associated loosening were studied. The original joint disease was rheumatoid arthritis (RA) $(n=8)$ and osteoarthritis $(O A)(n=21)$, five of which were secondary OA (post-traumatic, osteonecrosis, or congenital dysplasia/dislocation of the hip); data were not available for one patient. Table 1 lists brief clinical details of the patients.

Specimens of the bone-implant interface on the femoral, acetabular, or tibial side were obtained during revision of total hip replacement (THR) $(n=19)$, or total knee replacements $(T K R)(n=11)$. Small pieces of each sample were immediately embedded in OCT, snap frozen in liquid nitrogen cooled isopentane and stored at $-70^{\circ} \mathrm{C}$.

\section{IMMUNOHISTOCHEMISTRY}

Cryostat sections $5 \mu \mathrm{m}$ thick were cut from at least two frozen tissue blocks from each patient and left to dry at room temperature for a minimum of two hours. The sections were then fixed in a mixture of acetone/methanol $(50 / 50)$ at $-20^{\circ} \mathrm{C}$ for 10 minutes, washed with $0.05 \mathrm{~mol} / \mathrm{l}$ Tris- $\mathrm{HCl}$ buffered saline, $\mathrm{pH} 7.6$ (TBS), and stained with the biotin streptavidin alkaline phosphatase technique. Table 2 lists the antibodies used; they include: mouse monoclonal antibodies (MAb) to the adhesion molecules E-selectin, VCAM-1, ${ }^{28}$ ICAM-1; integrins LFA-1 (CD1 1a/CD18), C3bi receptor (CR3, CD11b/CD18); $T$ cell subsets CD4/ helper, CD8/suppressor, CD45RA naïve $T$ cells and CD45RO memory $T$ cells; also an antibody to macrophage associated antigen, CD68. A monoclonal antibody specific for prolyl 4-hydroxylase, an enzyme involved in the synthesis of collagens, was used as a marker of fibroblasts. A polyclonal rabbit anti-human Von-Willebrand factor (factor VIII) antibody was used for labelling of endothelial cells.

The tissue sections were incubated with the primary antibodies (diluted as shown in table 2) for one hour at room temperature. This was followed by one hour of incubation with biotinylated horse anti-mouse IgG. Alkaline phosphatase-streptavidin conjugate was added to all slides for one hour of incubation. Sections labelled with antibody to factor VIII related antigens were stained with 
Table 3 Histological pattern of the mononuclear cell infiltrate

\begin{tabular}{ll}
\hline Grade A & $\begin{array}{c}\text { Fibrous stroma with a thin layer of macrophage } \\
\text { infiltrate on the implant side (synovium-like } \\
\text { lining layer). }\end{array}$ \\
Grade B & $\begin{array}{c}\text { Increased vascular growth within the fibrous } \\
\text { stroma. Increased perivascular macrophage } \\
\text { infiltrate. Occasional FBGCs. } \\
\text { Replacement of the fibrous stroma with } \\
\text { different forms of macrophages. Presence of } \\
\text { a large number of FBGCs. }\end{array}$ \\
\hline
\end{tabular}

the indirect method using swine anti-rabbit alkaline phosphatase conjugate. All the conjugated antibodies were purchased from Vector Laboratories, Peterborough, UK, and used at 1/100 dilution. Each incubation was followed by three washes with TBS for five minutes each. The substrate reaction was developed using $5 \mathrm{mg}$ Naphthol AS-BI phosphate (Sigma) dissolved in $200 \mu$ l dimethylformamide. This was mixed with $10 \mathrm{ml}$ of $0.1 \mathrm{~mol} / 1$ Tris- $\mathrm{HCl}$ buffer ( $\mathrm{pH} 8.2$ ) and $10 \mathrm{mg}$ Fast Red TR salt (Sigma). Levamisole (final concentration $10^{-3} \mathrm{~mol} / \mathrm{l}$ ) was added as an inhibitor of endogenous alkaline phosphatase. The substrate solution was filtered and used immediately. After 20 minutes, sections were washed with TBS then with water, counterstained with Mayers haematoxylin and mounted in glycerine jelly (Dako) or aquamount (BDH). Negative controls to check for non-specific

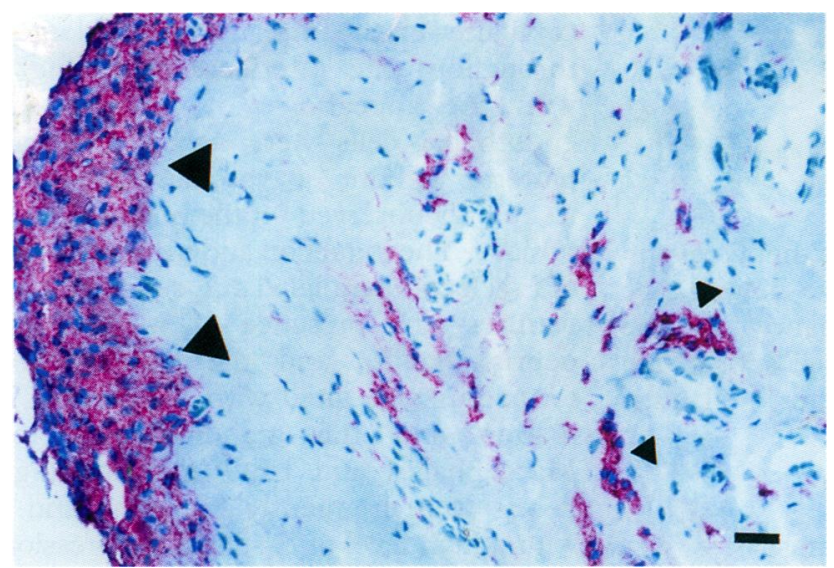

Figure 1 Staining for CD68 of a patient in grade $A$ shows a few layers of macrophages on the implant side (large arrow heads), also perivascular macrophages around vessels in the deeper layers of the interface (small arrow heads). Horizontal bar represents $10 \mu \mathrm{m}$.

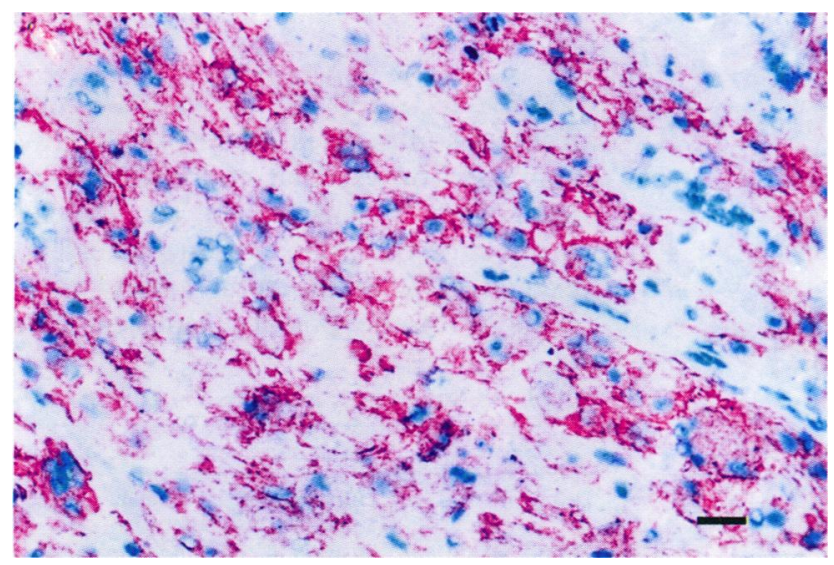

Figure 2 A patient in grade $C$ shows complete replacement of the fibrous stroma with macrophages and a large number of FBGCs stained positively for CD68. There is also a marked increase in vascular growth. Horizontal bar represents $10 \mu \mathrm{m}$. binding included replacing the primary antibody with TBS or non-immune immunoglobulin from the same species as the first antibody; in addition, one section from each patient was incubated with the substrate only, to exclude the detection of endogenous alkaline phosphatase in endothelial cells.

\section{Results}

A distinct pattern of vascular growth and a prominent macrophage and lymphocytic infiltrate were evident in the bone-implant interface obtained from the 30 patients studied. In addition, a variable number of FBGCs were present throughout the sections. All patients showed one or more types of particulate implant material within the cytoplasm of the phagocytic macrophages and FBGCs, in addition to that in the extracellular matrix. As macrophages predominate in these tissues, staining for CD68 highlighted the histological pattern of the cellular infiltrate, whereas staining for factor VIII revealed the characteristics of the vascular growth. The patients were classified into three grades depending on the pattern of distribution of the cellular infiltrate. Table 3 summarises the main features. Grade A (patients $1-6$ in table 1) represented tissues removed at early stages of the release of implant wear particles. These tissues consisted mainly of fibrous stroma with few layers of macrophages and small lymphocytic aggregates on the side of the tissue lining the implant (fig 1). The macrophages colocalised with the released wear particles which were restricted to that surface only. A variable but small number of microvessels with a vascular lumen were seen within the cellular infiltrate. Patients graded B (Nos 7-14 in table 1) showed an increased number of vessels in the fibrous stroma, particularly at the side adjacent to bone, and an increased perivascular macrophage infiltrate. Most of these macrophages showed dendritic/stellate morphology compared with those at the implant side. A variable number of FBGCs were also present. Patients classified as grade C (Nos 15-30 in table 1) showed complete transformation of the tissues into a granulomatous reaction with marked increase in the vascular growth and in the number of FBGCs (fig 2). The histological changes seen in grade $\mathrm{C}$ correlated with the migration of the particulate debris from the implant to the bone side within the interface. The changes were also related to the amount and size of various particles seen. Particulate wear debris detected included metal, ultra high molecular weight polyethylene (UHMWPE) and polymethylmethacrylate bone cement (figs 3, 4).

The other important feature was the frequent presence of $T$ lymphocyte aggregates. They formed a small proportion of the cellular infiltrate compared with the macrophages, and the number varied from one area to another within samples. An increased number of $T$ lymphocytes was observed in patients in grade $\mathrm{C}$ and in association with the presence of metal wear particles. Immunophenotypic 


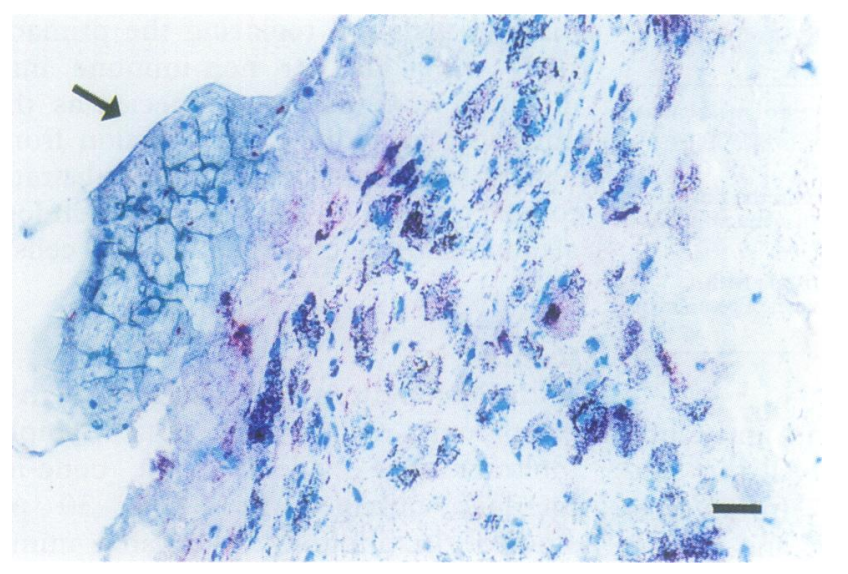

Figure 3 Heavy deposits of metal debris in the cytoplasm of macrophages and FBGCs. Also hydroxyapatite on the implant side (arrow). Horizontal bar represents $10 \mu \mathrm{m}$.

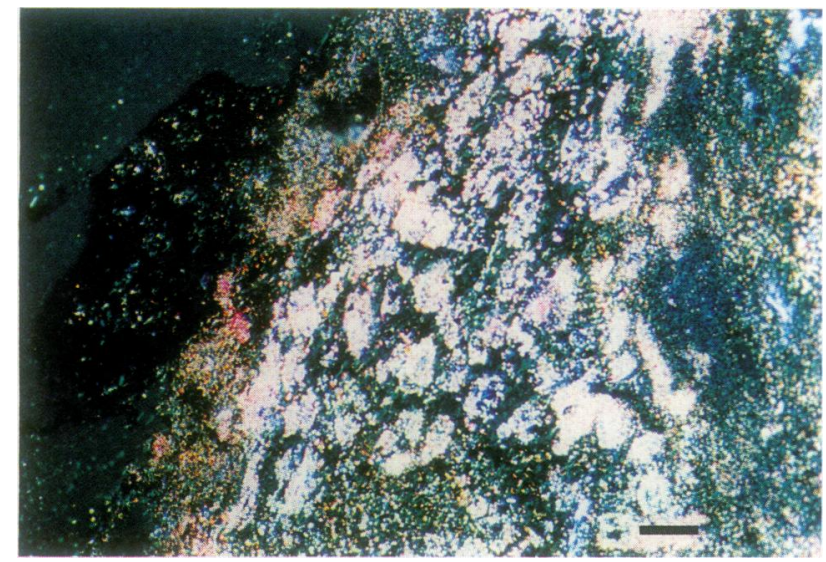

Figure 4 Same section as in figure 3 photographed with polarisation light shows polyethylene wear debris in the same cells. Horizontal bar represents $10 \mu \mathrm{m}$.

analysis showed that $60-70 \%$ of the $\mathrm{T}$ cells in the interface were $\mathrm{CD} 4$ positive helper type and they belonged predominantly to the CD45RO positive memory $T$ cell subset. No immunoreactivity with the monoclonal antibody to CD45RA was detected.

\section{TISSUE DISTRIBUTION OF THE ADHESION} MOLECULES

E-Selectin

Expression of E-selectin was confined to vascular endothelial cells. A variable number of vessels with E-selectin positive staining was

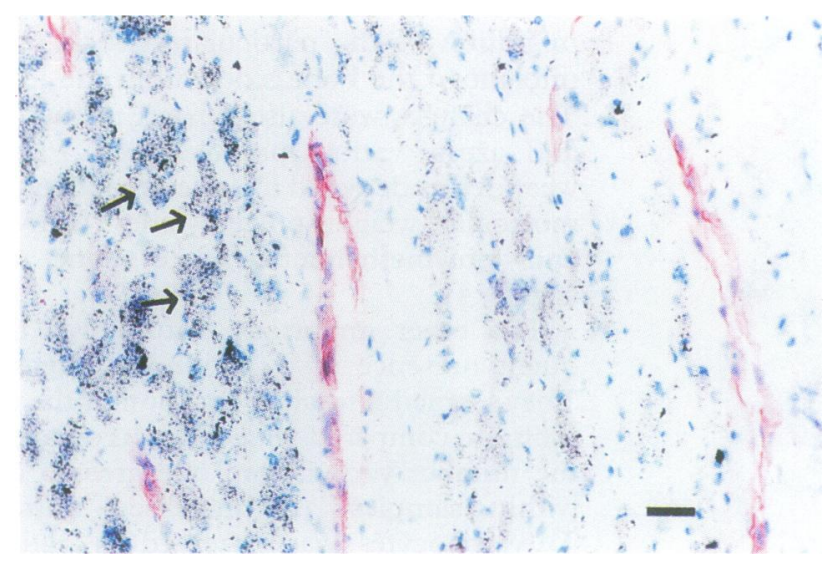

Figure 5 Expression of E-selectin in vessels adjacent to metal-debris-containing macrophages (arrows). Horizontal bar represents $10 \mu \mathrm{m}$.
Table 4 E-selectin expression on vascular endothelium

\begin{tabular}{llc}
\hline $\begin{array}{l}\text { Histological } \\
\text { grade }\end{array}$ & $\begin{array}{l}\text { No of } \\
\text { patients }\end{array}$ & $\begin{array}{c}\text { Vessels expressing } \\
\text { E-selectin (\%) }\end{array}$ \\
\hline Grade A & 2 & $5-10$ \\
& 2 & $70-80$ \\
Grade B & 2 & Negative \\
& 1 & 5 \\
& 3 & $70-60$ \\
& 2 & Negative \\
Grade C & 2 & $5-20$ \\
& 5 & $80-90$ \\
& 6 & Negative \\
\hline
\end{tabular}

found in 21 patients. Table 4 gives details of the staining results. There was no difference in the intensity of staining between the positive vessels. Scoring of positive vessels was performed on serial cryostat sections stained for factor VIII as a general marker expressed by all types of vessels and those stained for the adhesion molecule. The total number of vessels positive for factor VIII was quantified in one section and the number of E-selectin expressing vessels was counted in the adjacent section, so that the percentage of E-selectin expression in each patient was then determined. In the 21 positive subjects, the number of E-selectin expressing vessels varied between $5 \%$ and $90 \%$ and showed no distinct pattern of distribution within the sections. Upregulation of E-selectin was observed on different types of vessels including small capillaries on the implant side and large vessels throughout the interface. Migrating vessels with the appearance of a single layer of endothelial cells were arranged in a linear pattern without a vascular lumen. Those frequently observed on the bone side were also positive. The induction and increased expression of E-selectin paralleled and correlated with two features-the presence of metal particulate debris (fig 5), and the histological transformation associated with the chronic inflammation and the granulomatous reaction. Macrophages and FBGCs containing metal debris were frequently found around vessels with a high level of E-selectin expression in 11 patients. In the other 10 positive patients, UHMWPE was mainly detected with the polarisation light in the tissue sections, although a variable amount of metal and bone cement particles was also present.

\section{VCAM-1}

Table 5 summarises the results. VCAM-1 was expressed on vascular endothelium at a lower level than E-selectin, in six patients. The number of VCAM-1 expressing vessels did not exceed $40 \%$ of the total vessels seen in the sections of the positive samples. There was

\begin{tabular}{ll} 
Table 5 Summary of the expression of VCAM-1 \\
\hline No of patients & Tissue distribution of the positive staining \\
\hline 13 & $\begin{array}{l}\text { Superficial cells of the lining layer on the } \\
\text { implant side only }\end{array}$ \\
$\begin{array}{l}\text { Cells in the lining and sublining layers, } \\
\text { and vascular endothelium } \\
\text { Vessels expressing VCAM-1 }=5-40 \%\end{array}$ \\
Negative
\end{tabular}

Hod



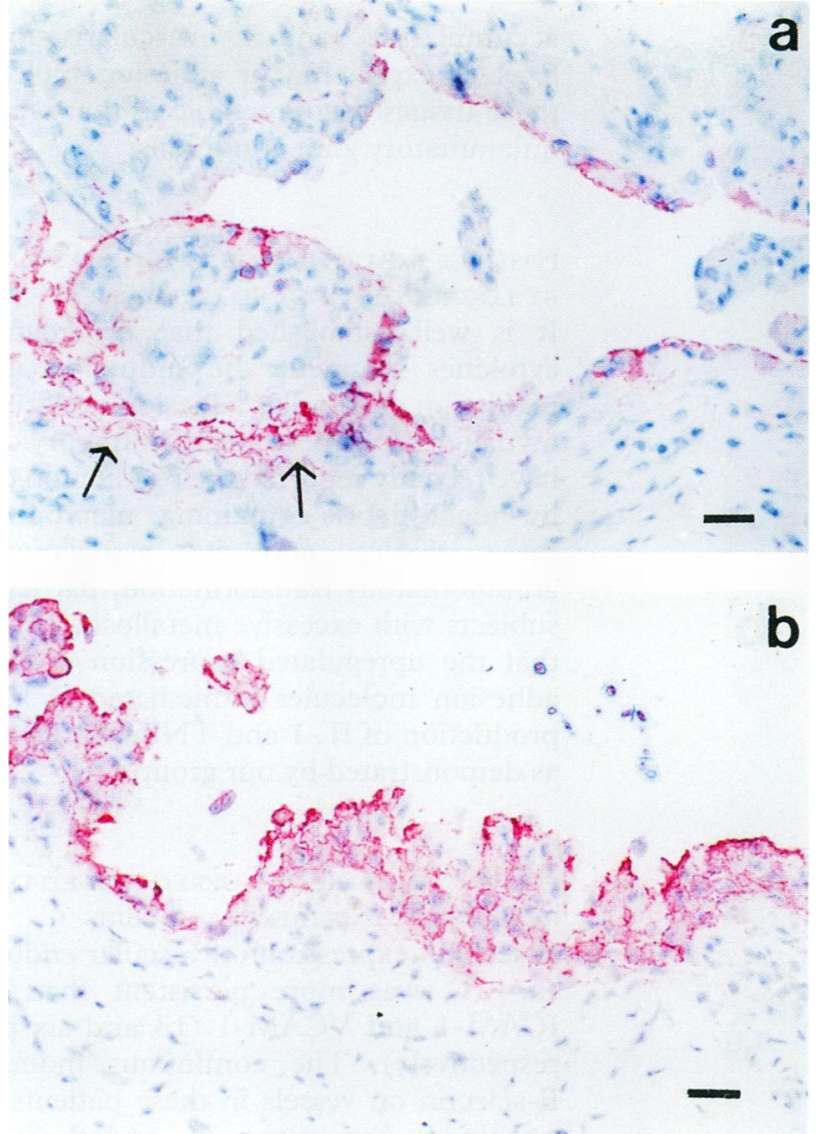

Figure 6 a: Immunoreactivity for VCAM-1 on the lining cells on the implant side is frequently seen (arrows). $\quad b$ : Expression of VCAM-1 in rheumatoid synovium (own observations). Few layers of the synovial lining cells are positive compared with a single layer in the interface. Horizontal bars represent $10 \mu \mathrm{m}$.

coexpression of E-selectin and VCAM-1 on endothelium in five subjects-one each in grade $\mathbf{A}$ and $\mathbf{B}$ and three in grade $\mathrm{C}$. Three of these patients showed marked upregulation of the two adhesion molecules in association with metal wear debris (E-selectin 70-90\% and VCAM-1 25-40\%). In addition to vascular endothelium, VCAM-1 was more frequently detected in the lining cells on the implant side $(n=13)$ (fig 6). The majority of the lining cells were positive for CD68. However, a proportion showed intense immunoreactivity with the $\mathrm{MAb} 5 \mathrm{~B} 5$ to prolyl hydroxylase. This enzyme catalyses the formation of 4-hydroxyproline in

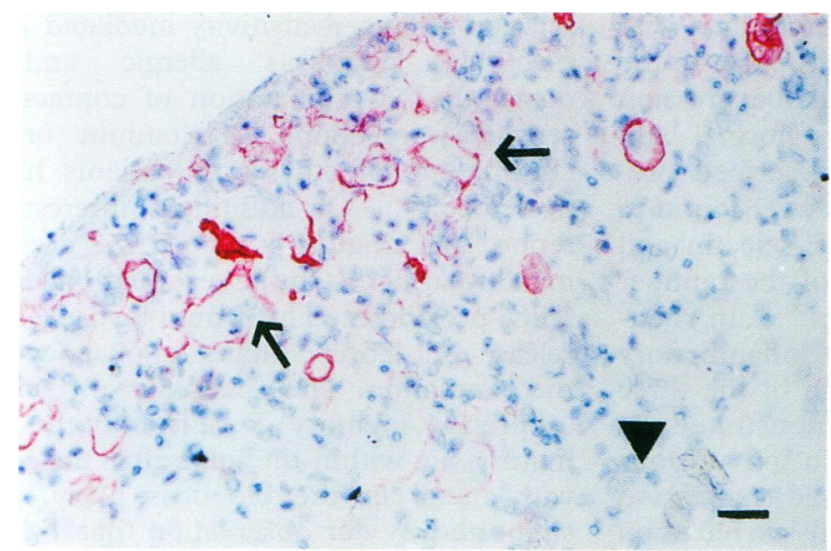

Figure 7 ICAM-1 was upregulated on macrophage subsets and FBGCs on the implant side (arrows), whereas FBGCs in the deeper layers lacked ICAM-1 expression (arrow head). Vascular endothelium was always negative in the superficial layers. Horizontal bar represents $10 \mu \mathrm{m}$. collagens and other proteins with collagen-like amino acid sequences. Immunostaining in this study also revealed that large concentrations of this enzyme are present in the chondrocytes of the newly formed cartilage in patients that show tissue remodelling on the implant side.

\section{ICAM-1}

A distinct pattern of distribution of ICAM-1 was observed in these tissues (table 6). Twenty six patients showed intense reactivity with vascular endothelium, and a variable number of macrophages and FBGCs were stained. ICAM-1 expression was restricted to the endothelium in four patients: two showed grade A histology and the other two were grade $B$ with a small number of giant cells which were negative.

In 13 of the positive patients, ICAM-1 was absent from all vessels, but was strongly expressed with bright staining on subsets of macrophages and FBGCs in the lining and sublining layers on the implant side (fig 7). ICAM-1 and VCAM-1 were localised in the superficial cells of the lining layer, whereas FBGCs expressed ICAM-1 only.

The last nine positive patients showed high expression of ICAM-1 on vascular endothelium and the lining cells. In two subjects, ICAM-1 expressing vessels were restricted to the bone side only. Aggregates of macrophages and FBGCs on the implant side of the tissue in this group of patients expressed large concentrations of ICAM-1 (fig 8). The induction and upregulation of ICAM-1 did not correlate with the presence of a particular type of wear debris detected in the sections.

\section{$L F A-1(C D 11 a / C D 18)$ and $C R 3$ (CD11b/CD18)}

Anti-LFA-1 MAb reacted strongly with the $T$ cell infiltrate in all patients. Marked expression of LFA-1 was also observed on macrophage subsets and FBGCs in eight patients, six of them in grade $C$ with metallosis and two in grade A with UHMWPE wear debris.

CR3 was constitutively expressed in large concentrations on different types of macrophages, particularly the perivascular infiltrate and the lining cells on the implant side. Interestingly, aggregates of macrophages and a variable number of FBGCs in the lining and sublining layers only exhibited simultaneous and increased expression of both ICAM- 1 and CR3. In comparison, FBGCs throughout the

Table 6 Results of the expression and distribution of ICAM-1

\begin{tabular}{ll}
\hline No of patients & Pattern of expression \\
\hline 4 & $\begin{array}{l}\text { Vascular endothelium only } \\
\text { Range of 10-75\% positive vessels } \\
\text { Macrophages and giant cells throughout } \\
\text { the lining layer on the implant side only. } \\
\text { Vascular endothelium negative }\end{array}$ \\
& $\begin{array}{l}\text { Vascular endothelium } \\
\text { Range of 5-30\% positive vessels } \\
\text { Macrophages and giant cells in the lining } \\
\text { and sublining layers on the implant side }\end{array}$ \\
& Negative \\
\hline
\end{tabular}



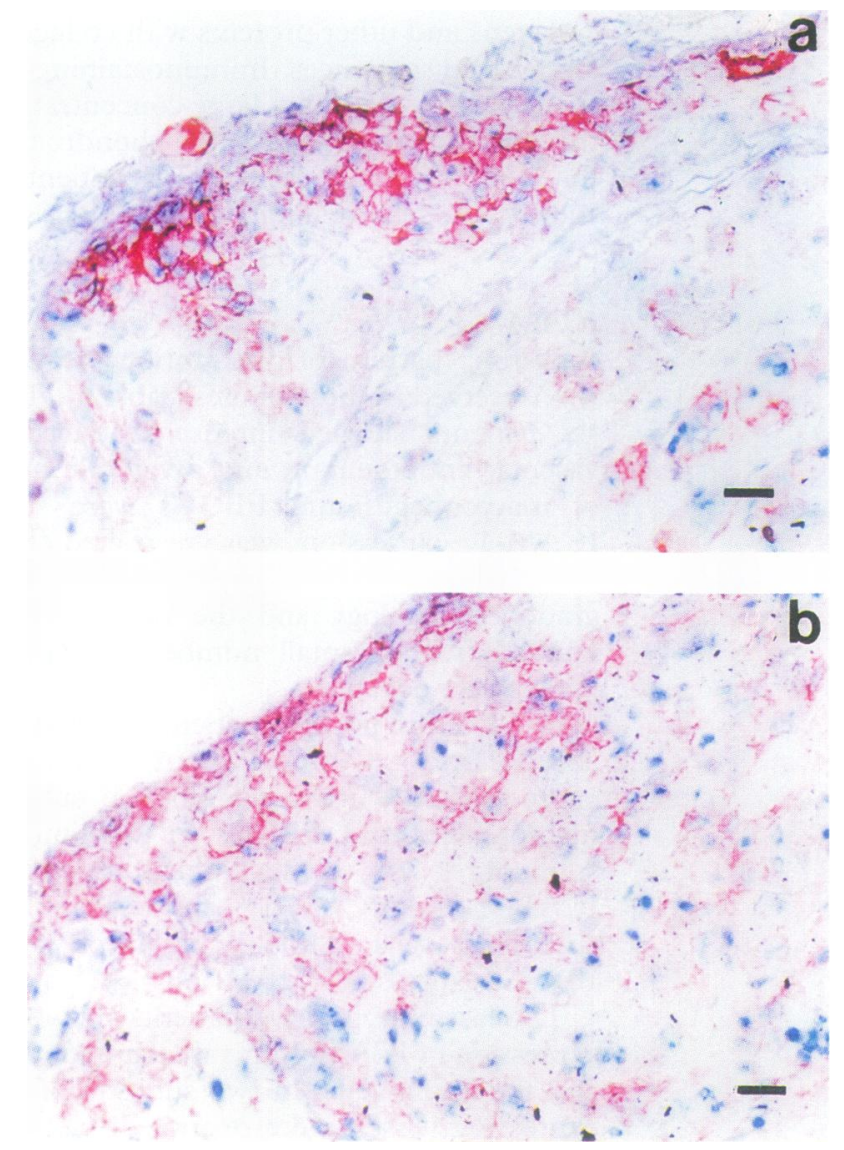

Figure 8 a: Increased ICAM-1 expression on macrophage aggregates on the implant side. Same aggregates co-express CR3 (not shown). b: Same patient shows high level of production of IL-1 on the implant side (previously reported finding ${ }^{35}$ ). FBGCs show membrane and cytoplasmic staining. Horizontal bars represent $10 \mu \mathrm{m}$.

interface showed a relatively lower level of expression of CR3, and lacked ICAM-1 expression.

\section{Discussion}

This study describes the histological pattern of vascular growth and demonstrates the induction and upregulation of three types of adhesion molecules-ICAM-1, E-selectin, and VCAM-1 - in the bone-implant interface, the fibrous membrane that develops around aseptically loosened orthopaedic prostheses. The findings support the clinical observation of the presence of a local chronic inflammatory reaction and the potential of particulate wear debris in the induction of this response. In the joint microenvironment, the level of expression of cell adhesion molecules in normal and inflamed synovium has been described previously. Normal synovial vessels were found to lack VCAM-1 and to express E-selectin and ICAM-1 at low level in terms of the number of vessels and staining intensity. ${ }^{29}{ }^{30}$ In rheumatoid joint and other types of inflammatory synovitis, upregulated expression of the three adhesion molecules has been demonstrated not only on endothelium but also on various synovial cells. ${ }^{31-34}$ This increased expression correlates with the presence and tissue retention of chronic inflammatory infiltrate. The boneimplant interface from aseptic loosening exhibits many signs of inflammation, including the presence of reactive $T$ cells, macrophage accumulation, and neovascularisation. The level of expression of adhesion molecules in these tissues is comparable to that reported in inflammatory joint conditions.

POSSIBLE INDUCTION OF ADHESION MOLECULES BY LOCALLY PRODUCED CYTOKINES

It is well established that proinflammatory cytokines augment the induction and upregulation of vascular adhesion molecules, and mediate recruitment of inflammatory cells. We have recently reported the production of IL-1 $\beta$ by metal-debris-containing macrophages in these tissues and its association with granulomatous transformation, particularly in subjects with excessive metallosis. ${ }^{35}$ It is likely that the upregulated expression of the three adhesion molecules is mediated by the local production of IL-1 and TNF $\alpha$ in these tissues as demonstrated by our group.

E-SELECTIN IS HIGHLY UPREGULATED IN RESPONSE TO METAL WEAR DEBRIS

E-selectin expression on vascular endothelium $(n=21)$ was more persistent than that of ICAM-1 and VCAM-1 (13 and six patients, respectively). The continuous induction of E-selectin on vessels in these patients reflects sustained activation of endothelial cells. Although this contrasts with the known transient expression of E-selectin on these cells in vitro even in the presence of inducing cytokines, ${ }^{16}{ }^{36}$ persistent upregulation of E-selectin has been previously described in chronic inflammatory conditions such as psoriasis. ${ }^{37}$ An important finding in this study was that E-selectin expression correlated significantly with the presence of metal debris which was identifiable in 11 of the 21 positive patients. Furthermore, among these patients VCAM-1 was co-expressed with E-selectin in three. E-selectin is known to mediate $T$ cell adhesion and migration, and naïve, resting, and activated memory $T$ cells utilise this pathway. ${ }^{38}$ The prolonged expression of E-selectin may contribute at least partially to the circulation of memory $T$ cells sensitised to metal. Upregulation of E-selectin and VCAM-1 on vascular endothelium has been reported in relation to hypersensitivity mediated immune reactions such as allergic and toxic dermatitis. ${ }^{39} 40$ Generation of contact hypersensitivity reactions to titanium or cobalt chrome hip prostheses in patients has been described. ${ }^{41-43}$ Of additional interest is the report by Panigutti et $a l^{44}$ on the presence of metal wear debris in the serum of patients with failed prostheses. This would be caused by the release of debris-containing phagocytes into the circulation. The possibility of recruitment of primed memory $\mathrm{T}$ cells into the inflammatory site within the joint after their contact with metal in the blood is likely. This is supported by our observation that $\mathrm{T}$ lymphocytes in the interface are frequently of the helper type and CD45RO positive. However, there is no direct evidence on the role of these cells in the initiation of the immune response 
to metal implants as they lack the expression of activation markers, including detectable IL-2 and IL-2 receptors. ${ }^{35}$

VCAM-1 plays a central role in T cell and monocyte adhesion through its interaction with the integrin VLA-4 which is expressed by these cells. ${ }^{24}{ }^{45}$ Unlike E-selectin, the VCAM-1 mediated pathway of adhesion requires activation of both the receptor and the ligand. ${ }^{46} 47$ The lack of expression of VCAM-1 on vascular endothelium in the majority of our patients suggests a limited contribution in the recruitment of inflammatory cells. VCAM-1, however, has been demonstrated in significant concentrations on vessels in inflammatory joint conditions such as rheumatoid arthritis. ${ }^{48} 49$

In addition to binding to VCAM-1 on endothelium, VLA-4 has an extracellular matrix ligand, CS1 of fibronectin. This adhesion pathway was found to be responsible for the binding and retention of $T$ cells in rheumatoid synovium..$^{50}$ As fibronectin is present in abundance in the bone-implant interface, further analysis of the expression of these important integrins on $T$ cells and on phagocytes should help to identify the precise mechanism of accumulation of these cells on the implant surface and their role in the development of local inflammatory response.

THE ROLE OF DIFFERENTIAL EXPRESSION OF ICAM-1 ICAM-1 expression was not restricted to endothelium in the bone-implant interface. Various other studies have also demonstrated its induction by other cells, including dendritic reticulum cells and $B$ cells of the lymphoid follicles in peripheral lymphoid tissues, ${ }^{52}$ in addition to macrophages, fibroblasts, epithelial cells, ${ }^{53}$ and bone marrow stromal cells. ${ }^{54}$ Assessment of inflamed synovial tissues by others $^{31} 34$ has further revealed the upregulation of ICAM-1 on type A and type B synovial lining cells, synovial macrophages, and endothelial cells.

In this study, ICAM-1 expression was more prominent on the lining cells (22 patients) than on vascular endothelium (13 patients). It was also more detectable on vessels in the deeper layer and absent from all small proliferating vessels of the lining layer on the implant side. This differential expression may suggest that ICAM-1 participation in transendothelial migration of cells in these tissues is restricted, and that its induction on lining cells may serve to regulate important cell-cell interactions and not endothelium-cell adhesion. The first explanation is consistent with our finding of the presence of perivascular $\mathrm{T}$ cell aggregates in the deeper layers in association with ICAM-1 positive vessels; $T$ cells in all patients showed significant expression of LFA-1, the receptor for ICAM-1.

The expression of ICAM-1 and CR3 on subsets of macrophage aggregates on the implant side may be of particular importance in maintaining a prolonged immune response at sites of particulate debris release. ICAM-1 has been shown to regulate immune functions requiring cell-cell contact ${ }^{55}$ and adherence of cells may regulate the process of cell activation mediated by the inflammatory cytokines, chemotactic factors and enzymes released by phagocytes. ${ }^{57}$ However, an additional function of these receptors in homotypic adhesion is possible. The role of ICAM-1 in homotypic adhesion has been best described in haematopoietic cell lines and tumours. Analysis of myeloid and lymphoid cell lines showed strong correlation between ICAM-1 expression and the formation of spontaneous cell aggregates. ${ }^{58}$ Likewise, ICAM-1 was found to be the major determinant involved in regulating tumour behaviour. Lymphomas with weak ICAM-1 expression were described to have a diffuse pattern of spread associated with a leukaemic process, whereas those with intense ICAM-1 expression show tightly aggregated large masses. ${ }^{51}{ }^{59}$ Phagocyte-phagocyte interactions mediated by ICAM-1/CR3 linkage may be essential in aggregation and immobilisation of distinct subsets at sites of antigenic stimulation. This suggestion is supported by our observation of persistent expression of both the receptor and the ligand on FBGCs in the superficial layers of the interface and not on macrophages and FBGCs in the deeper layers, which expressed CR3 only. The latter also showed larger amounts of wear debris, which suggests that they represent well differentiated giant cells. A recent report by our group revealed functional and phenotypic properties of these cells similar to those of osteoclasts. ${ }^{60}$ Further studies are in progress to explore the possible contribution of other integrins and the interactions of the adhesion molecules with the extracellular matrix proteins and their role in bone and cartilage remodelling around orthopaedic implants.

We wish to thank Dr D O Haskard, at The Royal Postgraduate Medical School, the antibodies to E-selectin, VCAM-1, and LFA-1. We are also the antibodies to E-selectin, VCAM-1, and LFA-1. We are also
grateful to Miss Enid Garraway for preparation of the manuscript. This project was supported by the Arthritis and Rheumatism Council (grant 52), UK.

1 Maloney W J, Jasty M J, Rosenberg A, Harris W H. Bone lysis in well-fixed cemented femoral components. $\mathcal{F}$ Bone foint Surg Br 1990; 72: 966-70.

2 Pierson J L, Harris W H. Extensive osteolysis behind an acetabular component that was well fixed with cement. f Bone foint Surg Am 1993; 75: 268-71.

3 Goldring S R, Schiller A L, Roelke M, Rourke C M, O'Neill D A, Harris W $\mathrm{H}$. The synovial like membrane at the bone-cement interface in loose total hip replaceat the bone-cement interface in loose total hip replace-
ments and its proposed role in bone lysis. $\mathcal{F}$ Bone foint Surg ments and its proposed ro

4 Levack B, Revell P A, Freeman M A R. Presence of macrophages at the bone-cement interface of stable hip arthroplasty components. Acta Orthop Scand 1987; 58: 384-97.

5 Goldring S R, Jasty $M$, Roelke M S, Rourke C M, Bringhurst F R, Harris W H. Formation of a synovial like membrane at the bone-cement interface. Its role in bone resorption and implant loosening after total hip replacement. Arthritis Rheum 1986; 29: 836-42.

6 Lalor P A, Revell P A. Cellular infiltrates near failed joint

7 prostheses. F Pathol 1988; 156: 65A. pathological response to loose cementless acetabular pathological response to loose cementless aceta

8 Pober J S, Cotran R S. The role of endothelial cells in inflammation. Transplantation 1990; 50: 537-44.
inter J S, Cotran R S. The role of end othelial

9 Duijvestijn A M, Kekhove M, Bargatze R F, Butcher E C. Lymphoid tissue- and inflammation-specific endothelial cell differentiation defined by monoclonal antibodies. f Immunol 1987; 138: 713-9.

10 Pober J S, Collins T, Gimbrone M A Jr, Libby P, Reiss C S. Inducible expression of class II major histocompatibility complex antigens and the immunogenicity of vascular endothelium. Transplantation 1986; 41: 141-5.

11 Warner S J C, Auger K R, Libby P. Interleukin-1 induces IL-1. II Recombinant human IL-1 induces interleukin 1 
production by adult human vascular endothelial cells f Immunol 1987; 139: 1911-7.

12 Wagner C R, Vetto R M, Burger D R. Expression of I-region-associated antigen (Ia) and interleukin 1 by subcultured human endothelial cells. Cell Immunol 1985; 93: $91-104$.

13 Pober J S. Cotran R S. What can be learned from the expression of endothelial adhesion molecules in tissues? Lab Invest 1991; 64: 301-5.

14 Osborn L. Leukocyte adhesion to endothelium in inflammation. Cell 1990; 62: 3-6.

15 Rothlein R, Dustin M L, Marlin S D, Springer T A. A human intercellular adhesion molecule (ICAM-1) distinct from LFA-1. F Immunol 1986; 137: 1270-4.

16 Bevilacqua M P, Pober J S, Mendrick D C, Cotran R S, Gimbrone M A. Identification of inducible endothelial leukocyte adhesion molecule. Proc Natl Acad Sci USA 1987; 84: 9238-42

17 Osborn L, Hession C, Tizard R, et al. Direct expression cloning of vascular cell adhesion molecule-1, a cytokine induced endothelial protein that binds lymphocytes. Cell 1989; 59: 1203-11.

18 Cotran R S, Gimbrone M A Jr, Bevilacqua M P, Mendrick D L, Pober J S. Induction and detection of a human endothelial activation antigen in vivo. 7 Exp Med 1986; 164: 661-6.

19 Bevilacqua M P, Stengelin S, Gimbrone M A, Seed B. Endothelial leucocyte adhesion molecule-1: an inducible receptor for neutrophils related to complement regulatory proteins and lectins. Science 1989; 243: 1160-5.

20 Bochner B S, Luscinskas F W, Gimbrone M A Jr, et al. Adhesion of human basophils, eosinophils and neutrophils to interleukin-1 activated human vascular endothelial cells: contributions of endothelial cell adhesion molecules. f Exp Med 1991; 173: 1553-6.

21 Picker L J, Takashi K, Kishimoto T K, Smith C W, Warnock R A, Butcher E C. ELAM-1 is an adhesion molecule for skin homing $\mathrm{T}$ cells. Nature 1991; 349: 796-9.

22 Bevilacqua M P, Pober J S, Wheeler M E, Cotran R S, Gimbrone M A. Interleukin-1 acts on cultured human vascular endothelium to increase the adhesion of polymorphonuclear leucocytes, monocytes and related leukocyte cell lines. F Clin Invest 1985; 76: 2003-11.

23 Dustin M L, Staunton D, Springer T A. Supergene families meet in the immune system. Immunol Today 1988; 9: 213-5.

24 Elices M J, Osborn L, Takada Y, et al. VCAM-1 on activated endothelium interacts with the leucocyte integrin VLA-4 at a site distinct from the VLA-4/fibronectin binding site. Cell 1990; 60: 577-84.

25 Haskard D O, Cavender D, Beatty P, Springer T A, Ziff M. T-lymphocyte adhesion to endothelial cells: mechanisms demonstrated by anti LFA-1 monoclonal antibodies. demonstrated by anti LFA-

26 Sanchez-Madrid F, Nagy J, Robbins E, Simon P, Springer T A. A human leucocyte differentiation antigen family with distinct alpha subunit and a common beta subunit: the lymphocyte function-associated antigen (LFA-1), the C3bi complement receptor (OKM-1/ Mac-1) and the P150,95 molecule. F Exp Med 1983; 158: 1785-803

27 Panayi G S. The immunopathogenesis of rheumatoid arthritis. Rheumatol Rev 1992; 1: 63-74.

28 Wellicome S M, Thornhill M H, Pitzalis C, et al. A monoclonal antibody that detects a novel antigen on endothelial cells that is induced by tumor necrosis factor, IL-1 or lipopolysaccharide. F Immunol 1990; 144: IL-1 or

29 Fairburn K, Kunaver M, Wilkinson L S, Cambridge G, Haskard D, Edwards J C W. Intercellular adhesion
molecules in normal synovium. Brf Rheumatol 1993; 32: molecul

30 Wilkinson L S, Poston R, Edwards J C W, Haskard D O. Expression of vascular cell adhesion molecule-1 in normal and inflamed synovium. $\mathcal{F}$ Lab Invest 1993; 68: 82-8.

31 Hale L P, Martin M E, McCollum D E, et al. Immunohistologic analysis of the distribution of cell adhesion molecules within the inflammatory synovial microenvironment. Arthritis Rheum 1989; 32: 22-30.

32 Haynes B F, Hale L P, Denning S M, Le P T, Singer $\mathrm{K} \mathrm{H}$. The role of leukocyte adhesion molecules in cellular interactions: implications for the pathogenesis of inflammatory synovitis. Springer Semin Immunopathol inflammatory synovi III: $163-85$.

33 Koch A E, Burrows J C, Haines G K, Carlos T M, Harlan $J$ M, Leibovich $S \mathrm{~J}$. Immunolocalization of endothelial and leucocyte adhesion molecules in human rheumatoid and osteoarthritic tissues. Lab Invest 1991; 64: $313-20$.

34 Szekanecz Z, Kenneth Haines G, Lin T R, et al. Differential distribution of intercellular adhesion molecules (ICAM-1, ICAM-2, and ICAM-3) and the MS-1 antigen in normal and diseased human synovia. The possible pathogenetic and clinical significance in rheumatoid arthritis. Arthritis Rheum 1994; 37: 221-31.

35 Al-Saffar N, Revell P A. Interleukin-1 production by activated macrophages surrounding loosened orthopaedic implants: A potential role in osteolysis. $\mathrm{Br} \mathcal{F}$ Rheumatol 1994; 33: 309-16.

36 Pober J S, Gimbrone M A, Lapierre L A, et al. Overlapping patterns of activation of human endothelial cells by interleukin-1, tumour necrosis factor and immune interferon. F Immunol 1986; 137: 1893-6.

37 Groves R W, Allen M H, Barker J N W N, Haskard D O Macdonald D $M$. Endothelial leucocyte adhesion molecule-1 (ELAM-1) expression in cutaneous inflammation. Br f Dermatol 1991; 124: 117-23.

38 Shimizu Y, Shaw S, Graber N, et al. Activation-independent binding of human memory $\mathrm{T}$ cells to adhesion molecule ELAM-1. Nature 1991; 349: 799-802.

39 Norris P, Poston R N, Thomas D S, Thornhill M Hawk J, Haskard D O. The expression of endothelial leukocyte adhesion molecule-1 (ELAM-1), intercellular enkesion molecule-1 (ICAM-1), and vascular cell adhesion molecule-1 (ICAM-1), and in experimental adhesion molecule-1 (VCAM-1) in experimental erythema and delayed hypersensitivity. $\mathcal{F}$ Invest Dermatol 1991; 96: 763-70.

40 Griffiths C E, Barker J N, Kunkel S, Nickoloff B J Modulation of leukocyte adhesion molecules, a T-cell chemotaxin (IL-8) and a regulatory cytokine (TNF- $\alpha$ ) in allergic contact dermatitis (rhus dermatitis). Brf Dermatol 1991; 124: 519-26.

41 Evans E M, Freeman M A R, Miller A J, VernonRoberts B. Metal sensitivity as a cause of bone necrosis and loosening of the prosthesis in total joint replacement. f Bone foint Surg Br 1974; 56: 626-42.

42 Benson M K D, Goodwin P G, Brostoff J. Metal sensitivity in patients with joint replacement arthroplasties. $B r$ Med f 1975; 4: 374-5.

43 Lalor P A, Revell P A, Gray A B, Wright S, Railton G T, Freeman M A R. Sensitivity to titanium, a cause of implant failure. $\mathcal{F}$ Bone foint Surg Br 1991; 73: 25-8.

44 Panigutti $M$ A, Merritt $K$, Bruner $R$ J, Kraay $M J$, Brown S A. Correlation of allergy, metal levels, implant alloy and implant damage in patients undergoing revision joint arthroplasty. Trans Soc Biomaterial 1992; 15: 7 .

45 Rice G E, Munro J M, Corless C, Bevilacqua M P. Vascular and nonvascular expression of INCAM-110. A target for mononuclear leucocyte adhesion molecule in normal and inflamed human tissue. Am 7 Pathol 1991; 138: 385-93.

46 Shimizu Y, van Seventer G A, Horgan K J, Shaw S. Roles of adhesion molecules in $\mathrm{T}$ cells recognition. Fundamental similarities between four integrins on resting human T cells (LFA-1, VLA-4, VLA-5, VLA-6) in expression, binding and costimulation. Immunol Rev 1990; 114: 109-43.

47 Shimizu Y, Newman W, Gopal T V, et al. Four molecula pathways of $T$ cell adhesion to endothelial cells: roles of LFA-1, VCAM-1, and ELAM-1 and changes in pathway hierarchy under different activation conditions. $\mathcal{f}$ Cell Biol 1991; 113: 1203-12.

48 van Dinther-Janssen A C H M, Horst E, Koopman G, et al. The VLA-4/VCAM-1 pathway is involved in et al. The adhesion to endothelium in rheumatoid synovium. F Immunol 1991; 147: 4207-10.

49 Edwards J C W, Wilkinson L S, Speight P, Isenberg D A. Vascular cell adhesion molecule 1 and $\alpha 4$ and $\beta 1$ integrins in lymphocyte aggregates in Sjogrens syndrome an rheumatoid arthritis. Ann Rheum Dis 1993; 52: 806-11.

50 Rodriguez R M, Pitzalis C, Kingsley G H, Henderson E Humphries M J, Panayi G S. T lymphocyte adhesion to fibronectin (FN): a possible mechanism for $\mathrm{T}$ cell accumulation in the rheumatoid joint. Clin Exp Immunol 1992; 89: 439-45.

51 van Dinther-Janssen A C H M, Pals S T, Scheper R J, Meijer C J L M. Role of the CS1 adhesion motif of fibronectin in $\mathrm{T}$ cell adhesion to synovial membrane and peripheral lymph node endothelium. Ann Rheum Dis 1993; 52: 672-6.

52 Wawryk S O, Novotny J R, Wicks I P, et al. The role of LFA-1/ICAM-1 interaction in human leucocyte homing and adhesion. Immunol Rev 1989; 108: 135-61.

53 Dustin M L, Rothlein R, Bhan A K, Dinarello C A Springer T A. Induction by IL-1 and interferon $\gamma$ : Tissu distribution, biochemistry and function of a natura adherence molecule (ICAM-1). f Immunol 1986; 137: 245-54.

54 Novotny J R, Duehrsen U, Welch K, Layton J E, Cebon J S, Boyd A W. Cloned stromal cell lines derived from human Whitlock/Whitte-type ong-term bon marrow cultures. Exp Hematol 1990; 18: 775-84.

55 Boyd A W, Wawryke S O, Burns G F, Fecondo J V Intercellular adhesion molecule-1 (ICAM-1) has a central role in cell-cell contact mediated immune mechanisms. Proc Natl Acad Sci USA 1988; 85: 3095-9.

56 Dougherty G J, Murdoch S, Hogg N. The function of human intercellular adhesion molecule-1 (ICAM-1) in the generation of the immune response. Eur 7 Immunol 1988; 18: 35-9.

57 Carlos T M, Harlan J M. Membrane proteins involved in phagocyte adherence to endothelium. Immunol Rev 1990; 114: $5-28$.

58 Makgoba M W, Sanders M E, Luce G E G, et al. ICAM-1, the ligand for LFA-1 dependent adhesion of $\mathrm{B}, \mathrm{T}$ and myeloid cells. Nature 1988; 331: 86-8.

59 Boyd A W, Dunn S M, Fecondo J V, et al. Regulation of expression of a human intercellular adhesion molecule ICAM-1 during lympho-hemopoietic differentiation. Blood 1989; 73: 1896-903.

60 Kadoya Y, Al-Saffar N, Kobayashi A, Revell R A. The expression of osteoclast markers on foreign body giant cells. Bone Miner 1994. In press. 